\title{
Ritus Budaya Tingkeban Sebagai Perekat Sosial Pada Masyarakat Jember
}

\author{
Dhimas Abror D, Ana Nailun Najah, Indri Mar’atus Sholiha, Nellasari Agustin
}

\author{
Program Studi Sosiologi, FISIP, Universitas Jember \\ Email: dimas.juraid@gmail.com
}

\begin{abstract}
Abstrak
Indonesia sebagai negara multikultural memiliki beragam budaya yang memiliki identitas berbeda sesuai dengan daerah. melalui keberagaman ini dapat menyongsong nama Indonesia menjadi negara yang kaya akan budaya dan dapat dikenal di seluruh dunia. Budaya memiliki makna yang berbeda-beda di setiap daerah. Salah satu budaya yang ada di daerah Jember salah satunya "Ritus Budaya Tingkeban" yang berfungsi sebagai perekat sosial pada masyarakat. Ritus budaya tingkeban ini merupakan upacara yang dilakukan sebagai bentuk kehormatan dalam kehamilan usia 7 bulan seorang ibu. Penelitian ini bertujuan untuk mengetahui bentuk rangkaian tingkeban sebagai perekat sosial dari masyarakat Jember. Penelitian ini dilakukan melalui metode kualitatif dengan pendekatan deskriptif sedangkan teknik pengumpulan data melalui observasi dan wawancara pada masyarakat Jember.
\end{abstract}

Kata Kunci: Tingkeban, Jember, Perekat sosial

\section{Pendahuluan}

Dewasa ini kita memasuki zaman modern dimana zaman sudah dikatakan modern pada tahun 1.500 keatas yang telah ditandai dengan runtuhnya Kekaisaran Romawi Timur (Wikipedia, 2020). Masa ini didukung juga dengan perkembangan yang begitu besar di bidang ilmu pengetahuan, politik dan juga teknologi. Dalam masyarakatnya juga mengalami perubahan pola pikir akibat pengaruh dari perubahan pengetahuan maupun teknologi. Setiap masyarakat memiliki kepercayaan maupun budaya yang di percayai dan dianut oleh mereka. Indonesia merupakan negara yang beraneka ragam akan segala hal termasuk budaya yang dimiliki seperti halnya tradisi pernikahan, kehamilan dan kematian. Nenek moyang memberikan warisan budaya pada generasinya. Pada saat itu nenek moyang memiliki warisan seperti tradisi dimana dulunya sangat kental dan sangat dipercayai yang kemudian diberikan pada generasinya agar diteruskan dan dijaga supaya tidak hilang. Dari generasi ke generasi pastinya mengalami perubahan yang terjadi didukung dengan perkembangan pengetahuan dan teknologi yang membuat pola pikir masyarakat juga berubah. Pada awalnya masyarakat sangat terbuka dan menerima begitu saja akan warisan budaya dari nenek moyang yang pada akhirnya mengalami perubahan akibat pengetahuan yang dimiliki. Masyarakat menjadi tidak mudah menerima suatu budaya yang menurutnya tidak nyata dalam kehidupan sehariharinya (Ardra, 2020).

Budaya tingkeban atau mitoni merupakan sebuah ritus yang ditujukan untuk memperingati kehamilan seorang ibu yang memasuki usia 7 bulan sangat dipercayai oleh masyarakat jawa. Namun, tidak menutup kemungkinan bagi masyarakat yang lain juga banyak yang mengikuti dan mempercayai budaya tingkeban tersebut. Budaya tingkeban atau mitoni yaitu sebuah tradisi masyarakat jawa dimana diambil dari kata mitoni yang berasal dari kata pitu atau tujuh, tradisi upacara ini dilaksanakan saat kehamilan seorang ibu memasuki usia 7 bulan (Chandrarini, 2020). Dimana nenek moyang memberikan warisan budaya ini pada generasinya dan mengajarkan tradisi atau kegiatan apa saja yang harus dilakukan saat tingkeban. Kegiatan yang dilakukan seperti halnya siraman, upacara ganti pakaian. Kegiatan seperti itu oleh generasi dulu sangat dipercaya dan patuh untuk dilakuikan. Masyarakat sangat menghargai dan menjaga warisan tersebut agar tidak punah.

Kebudayaan akan melahirkan fenomena dalam merealisasikan masyarakat. Sesuai dengan naluri manusia bahwasanya yang ada pada penghormatan tradisi dan juga perasaan dalam setiap individu muncul rasa ketakutan ketika melanggar tradisi yang sudah dilakukan pendahulu. Tradisi dan budaya memang selalu melekat dalam agama. Salah satu budaya yang ada di masyarakat Jawa yang mengandung kearifan lokal yaitu ritual 
kelahiran. Ritual kelahiran terdapat banyak sekali macamnya, namun kini penulis menggunakan ritual tingkeban (tujuh bulanan) yang biasanya dilakukan sebelum lahiran, dapat dikatakan puncak dalam kelahiran dimana bayi sudah akan keluar dari kandungan. Secara struktural tradisi tingkeban ini mengandung nilai-nilai didalamnya (etika dan religius). Tingkeban ini namun tidak secara keseluruhan dilakukan disetiap masyarakat, hanya saja masyarakat yang masih memiliki budaya yang sama yang telah ada dalam peninggalan nenek moyang. Dapat dikatakan juga hanyalah terdapat dalam suatu kepercayaan dalam setiap individu. Banyak macam cara masyarakat meneladani ritual ini, ada yang hanya membuat makanan, membuat acara tasyakuran yang besar. Namun juga dalam setiap lahiran tersebut juga biasanya yang dilakukannya ritual hanya pada waktu tujuh bulan kandungan. Untuk umur tiga bulan, lima bulan tersebut dilakukan hanya biasa saja. Pada zaman saat ini memang kita berada dalam pembulatan globalisasi, dimana banyak muncul teknologi yang baru sehingga mempengaruhi kepercayaan yang dianut berubah hingga saat ini.

Ditengah arus globalisasi yang masif saat ini tingkeban menjadi salah satu budaya yang turun temurun dilakukan sebagian masyarakat. Seiiring berjalannya waktu memasuki zaman modern ini kondisi budaya mengalami perubahan. Sehingga pada generasi saat ini sudah mulai mengalami perubahan dimana masyarakat ada yang tetap mempercayai budaya tingkeban tersebut dan ada pula yang hanya melakukukan tradisi ini sekedar formalitas tanpa ada rasa kepercayaan yang penuh akan budaya tingkeban tersebut karena dipengaruhi oleh fakta sosial dimasyarakat. Meskipun secara kuantitas mengalami penurunan sejatinya ritus ini memiliki fungsi sosial dalam kehidupan masyarakat antara lain sebagai perekat sosial antara masyarakat. Dalam kehidupan masyarakat yang dinamis tentunya akan rawan mengalami gesekangesekan yang nantinya dapat memicu sebuah konflik, kemudian hal ini menjadi semakin rawan ketika masyarakat modern cenderung lebih individualis daripada mementingkan kepentingan kolektif, oleh sebab itu diperlukan perekat sosial yang dapat memelihara hubungan masyarakat. Tingkeban menjadi salah satu kegiatan yang mampu melakukannya, oleh sebab itu budaya ini patut untuk dilestarikan masyarakat.

\section{Metode}

\section{Metode Penelitian}

Penelitian ini menggunakan metode penelitian kualitatif dengan jenis penelitian lapangan. Metode penelitian kualitatif adalah metode penelitian yang berlandaskan pada filsafat postpositivisme atau enterpretif, dimana realitas sosial dilihat sebagai suatu yang holistic, kompleks, dinamis dan penuh makna dan penelitian kualitatif pada awalnya metode ini lebih banyak digunakan untuk penelitian bidang antropologi budaya (Desitania, 2016)

Penelitian kualitatif juga memiliki pengertian sebagai suatu pendekatan penelitian yang dilakukan dengan metode observasi atau pengamatan dan dengan dialog atau wawancara dengan narasumber yang ada kaitannya serta sesuai dengan obyek penelitian yang diteliti (Mulyadi, 2011)

Pada penelitian kualitatif ini akan menggunakan metode deskriptif. Dimana hasil dari penelitian ini akan disampaikan secara deskriptif, yaitu data yang dihasilkan dalam penelitian ini kemudian saling dielaborasi untuk menghasilkan sebuah hasil penelitian yang bersifat deskriptif mengenai obyek sosial yang diteliti. Penelitian deskriptif dengan tujuan untuk menjelaskan hasil penelitian dengan data yang telah didapat saat di lapangan. Pengumpulan data dalam penelitian ini menggunakan metode wawancara dan juga melakukan observasi kepada masyarakat jember yang masih menjalankan budaya tingkeban. Observasi merupakan salah satu metode pengumpulan data dengan melakukan pengamatan secara langsung terhadap fokus penelitian yang dilakukan. Penelitian ini dilakukan dengan cara participant of observe. Peneliti ikut berkecimpung secara langsung dalam proses acara tingkeban tersebut. Wawancara merupakan sebuah proses dimana terjadi antara informan dan peneliti saling bertemu diwaktu dan tempat yang sama. Wawancara juga bisa dipahami sebagai proses peneliti bertanya pada informan mengenai pokok penelitian secara mendalam untuk mendapat informasi yang akurat, tepat dan dapat dipertanggungjawabkan. Wawancara dilakukan dengan memberikan pertanyaan terbuka kepada informan yang merupakan masyarakat Jember. 


\section{Pembahasan}

\section{Makna Budaya Tingkeban di Jember}

Berbicara mengenai makna, penulis kini menggunakan teori dari van gennep sebagai acuan penulis dalam mengambil topik pembahasan tingkeban. Dapat penulis simpulkan, bahwasanya didalam teori ini tidak hanya membahas mengenai kelahiran, namun juga kematian, dan budaya yang lainnya. Namun van gennep dalam penulisannya menyampaikan bahwasanya dari berbagai jenis penelitian yang ia tuliskan, ia lebih menarik untuk menuliskan mengenai kelahiran, dengan alasan didalam ide tersebut bahwa kelahiran itu memiliki budaya yang sangat banyak sehingga dapat dibedakan dengan budaya yang lainnya, juga dapat memperlihatkan kaum muda/remaja masih tetap mengikuti budaya yang kuno atau sebaliknya. Juga dijelaskan bahwa transisi dari status sosial yang satu dengan yang lainnya meliputi 3 tahapan diantaranya perpisahan, peralihan dan penggabungan. Ritual ini difungsikan untuk mengkontrol sosial dalam masyarakat yang konservatif untuk mengatur perilaku dan serangkaian nilai untuk menjaga kepercayaan dalam diri individu sejak turun temurun. Van Gennep telah membedakan ritual kelahiran, bahwa ritual ini difokuskan pada anak yang baru lahir serta ibu hamil dan ayah (Forth, 2020). Namun sebelum adanya kelahiran tentu dalam proses kehamilan (tingkeban). Kelahiran/tingkeban diartikan sebagai tradisi yang biasa dilakukan oleh masyarakat budaya Jawa. Masyarakat jawa biasanya mengenalkan budaya tersebut dengan nama mitoni, karena tingkeban ini dilakukannya pada saat kandungan seorang ibu berusia 7 bulan. Ritual ini digunakan dengan tujuan agar bayi dan ibunya selamat. Dan juga mitoni ini diartikan bahwa dilakukan dengan ritual ini untuk sambutan bayi yang ada dalam kandungan ibu. Ritus kelahiran ini dapat memisahkan wanita yang hamil dengan masyarakat pada umumnya sehingga tejadilah persalinan yang memisahkan anak dari rahim dan ibu.

Tingkeban di wilayah jember khususnya di perkotaan bahwasanya tingkeban diartikan bahwa budaya yang datang dari turun temurun nenek moyang yang selalu dilakukan untuk menjaga/ menghormati bayi yang akan lahir (Forth, 2020). Pada wilayah ini, saat ini karena zaman atau ilmu yang dimiliki lebih modern, adat/budaya yang ada tidak sesuai dengan peninggalan nenek moyang kita yang lebih ramai/ lebih general. Namun untuk saat ini, masyarakat perkotaan jika melakukan ritual ini hanya diselenggarakan secara kecilkecilan bahkan hanya dilakukan biasa saja, sehingga dapat dikatakan tidak unik lagi. Tingkeban ini menurut masyarakat bukan suatu budaya yang wajib dilakukan katanya, karena masing-masing yang hidup dikota tersebut percaya akan dirinya sendiri, yang melakukan budayanya pun juga hanya $20 \%$ nya saja. Selebihnya tidak melakukannya. Pudarnya suatu kebudayaan itu memang bisa dikatakan dari munculnya teknologi yang sangat canggih, maupun informasi atau ilmu yang dimiliki saat ini semakin melebar, sehingga tidak lagi percaya dengan kebudayaan yang telah diwariskan oleh nenek moyang ini. Kebudayaan memang seharusnya tertanamkan namun apabila masyarakat perkotaan sudah berbeda lagi dalam mengartikan suatu kebudayaan.

\section{Ritus Budaya Tingkeban di Daerah Jember}

Budaya tingkeban merupakan salah satu tradisi selametan yang ada di dalam upacara mitoni masyarakat jawa. Upacara mitoni sendiri merupakan kegiatan selametan yang dilakukan oleh ibu hamil. Upacara tingkeban bermakna memberikan pendidikan semenjak benih tertanam di dalam rahim ibu. Banyak masyarakat Jember yang masih menjalankan tradisi tingkeban di derahnya. Alasan mereka menjalankan budaya ini karena budaya tingkeban sendiri merupakan budaya lokal yang harus dijalankan turun temurun kareena sudah menjadi tradisi warisan dari nenek moyang mereka. Selain itu, ada rasa takut tersendiri jika mereka tidak menjalankan tradisi dari warisan nenek moyang mereka. Tujuan mereka mengadakan budaya tingkeban ini sebagai rasa syukur karena telah diberikan amanah dengan dititipkanya janin ke rahim sang ibu.

Ada banyak jenis selametan dalam budaya tingkeban yang dilakuakan oleh masyarakat Jember antara lain: selametan tiga bulanan, selametan empat bulanan, selametan lima bulanan dan selametan tuju bulanan. Selametan empat bulanan dilakukan bertujuan untuk menipkan ruh kepada si janin dan selametan ini dilakukan supaya si janin selalu sehat serta selamat. Namun, dari banyaknya jenis selametan budaya tingkeban itu, mayoritas masyarakat Jember mengadakan selametan besar-besaran waktu usia kehamilan tujuh bulan, oleh karena itu mengapa upaca dari budaya tingkeban ini disebut mitoni (pitu dalam bahasa jawa). Mitoni dilakukan karena tujuh bulanan ini merupakan pintu awal mau memasuki 
fase kelahiran atau fase terakhir memasuki fase kelahiran. Oleh karena itu, mitoni ini dilakukan bertujuan untuk meminta keselametan si cabang bayi agar proses kelahiranya dapat berjalan dengan lancar.

Persiapan selametan tingkeban dilakukan selama dua hari. Satu hari dilakukan untuk mempersiapkan makanan yang akan disajikan dalam upacara mitoni dan hari selanjutnya digunakan sebagai inti dari acara tersebut. Rangkaian ritual tingkeban untuk pagi harinya diadakan siraman dengan menggunakan kembang atau bunga tujuh rupa dan gayung yang dipakai dari batok kelapa. Dalam ritual pandebeh atau siraman sang ibu hamil membawa kelapa muda yang diberi tulisan aksara jawa ataupun gambar wayang yang kemudian kelapa muda itu dibelah oleh sang suami untk mengetahui jenis kelamin dari bayi mereka. Jika kelapa dibelah pas digaris tengah itu menandakan bahwa anak yang kelak dilahirkan adalah perempuan dan jika kelapa yang dibelah tidak pas digaris tengah dalam artian miring itu meandakan bahwa kelak anak yang mereka lahirkan adalah laki-laki. Pakaian yang digunakan sang ibu dalam proses siraman tidak ada kostum khusus, mereka hanya menggunakan sewek dan untuk sang ayah mereka hanya menggunakan sarung. Seseorang yang ingin melakukan siraman harus mengantri sesuai urutan mulai dukun beranak, sesepuh (orang-orang tua) dan selanjutnya anak muda. Setelah proses siraman selesai sang ibu kemudian berganti pakaian dengan tujuh warna yang beda dan tujuanya agar bayi pantas dalam memakai baju dengan berbagai warna. Untuk malam harinya dilakukan acara selametan dengan membaca Surat Yasin, Surat Maryam, Surat Yusuf dan surat-surat penting lainya. Dalam tradisi tingkeban ada makanan khusus yang harus disajikan dalam acara tersebut yaitu urap-urap yang ditambah dengan tewel atau kluweh, makana itu dipilih karena memunyai makna untuk menambah rezeki dari sang bayi. Selain itu, juga disajikan bebrapa jenis jajanan yang ditrauh dalam satu wadah dan biasanya ciri khas makanan dari acara tingkeban ini adalah dawet dan rujak mangga.

Budaya tingkeban yang dilakukan oleh masyarakat Jember tidak hanya dilakukan dalam sebagai ritual kehamilan saja, namun tingkeban juga dilakukan sebagai ritual untuk selametan setelah kelahiran. Selametan yang dijalankan setelah mlehirkan adalah selametan coplok puser, selapan dan aqiqoh. Proses yang dijalankan dalam selametan-selametan itu hampir sama dengan proses selametan yang dilakukan dalam proses mitoni. Namun, yang membedakan dalam selametan selapan, coplok puser maupun aqiqoh tidak ada proses siramnya. Mereka hanya mengadakan selametan pembacaan doa-doa di malam harinya. Masyarakat Jember biasanya mengadakan selametan coplok puser disertakan dengan pemberian nama kepada sang bayi dan untuk selametan selapan mereka gabungkan dengan selametan aqiqoh yaitu acara memotong rambut sang bayi. Namun, budaya tingkeban untuk sekarang diaman zaman yang sudah modern, budaya ini sudah mulai ditinggalkan khususnya pada anak muda. Mereka yang masih melakukan budaya tingkeban ini pun hanya sebagai formalitas saja yang hanya mengikuti anjuran dari orang tua mereka, tanpa mengetahui filososfi atau makna dari budaya tingkeban sendiri.

\section{Solidaritas Sosial Dalam Ritus Tingkeban}

Tingkeban merupakan sebuah ritus yang ditujukan untuk bersyukur dalam rangka tujuh bulan kehamilan. Dewasa ini ritus ini mulai jarang dilakukan oleh masyarakat yang semakin modern dan menganggap hal ini terlalu kuno. Awalnya ritus ini hadir sebagai sebuah sarana untuk menghilangkan rasa cemas calon orang tua terdahulu terhadap kehamilan dengan melakukan selametan sebagai bentuk syukur sekaligus meminta kesalamatan sang bayi. Dalam penelitian kami menunjukkan bahwasannya ritus ini masih berlangsung di jember ditengah-tengah globalisasi dan perubahan masyarakat menjadi modern, ritus ini masih berada dalam eksistensinya. Meskipun dalam pelaksanaannya mengalami penyederhanaan dari waktu ke waktu akan tetapi esensi dari tingkeban masih sangat kental.

Sebagai sebuah realitas sosial yang ada di masyarakat, tingkeban menjadi fakta sosial yang kemudian mempengaruhi tindakan masyarakat melakukannya dilingkungan sosial. Sejatinya individu bebas untuk menentukan bagaimana bertindak akan tetapi ada hal diluar manusia yang bersifat memaksa. Masyarakat dengan berbagai nilai dan norma yang ada didalamnya kemudian menjadi cara bertindak yang berkembang dalam masyarakat itu sendiri. Dalam kegiatan tingkeban ini menjadi bentuk realitas yang ada di masyarakat yang secara tidak langsung mengatur masyrakat di jember untuk melakukannya secara kolektif. Dalam penuturan salah satu informan mengatakan: "Kalau menurut saya, acara tasyakuran seperti itu hanya sebagai formalitas saja atau sebagai syarat yang 
diajarkan dari nenek moyang kita. Dan acara itu dilakukan hanya untuk mendapatkan doa-doa dari masyarakat sekitar untuk keselamatan kandungan dari ibu yang sedang hamil itu". Dalam penjelasan ini dapat dilihat bahwasannya tingkeban ini menjadi sebuah fakta sosial yang "memaksa" individu di lingkungan sosial agar tidak mendapatkan sanksi sosial dalam masyarakat. "Kalau untuk symbol itu sendiri saya kurang paham mbak, karena sebagai anak-anak muda sendiri kita hanya mengikuti alurnya saja, hanya sekedar tau tanpa mengerti maknanya". Hal ini kemudian diperkuat dengan generasi muda yang mulai kehilangan esensi dari sebuah tingkeban yang sebenarnya sarat akan makna dan manfaat sosial di dalamnya. Akan tetapi tingkeban ini justru membangun solidaritas sosial di dalam masyarakat itu sendiri.

Solidaritas sosial sendiri muncul dari konstruk kesadaran kolektiv yang dibangun melalui fakta sosial yang mempengaruhinya. Dalam konsepnya durkheim membagi konsep solidaritas menjadi dua yaitu solidaritas mekanik dan solidaritas organik (Hasbullah, 2012). Dalam kaitannya di jember sendiri merupakan solidaritas mekanik yang ruang lingkup dan aturanya bersifat koersif, hal ini dilakukan masyarakat untuk menekan pelanggaran yang memicu penyimpangan terhadap kesadaran kolektif yang ada di masyarakat. Dalam hal ini tingkeban membangun solidaritas sosial yang didasarkan bahwa homogenitas terkait kepercayaan, sentimen dan lain sebagainya sehingga ketika sesorang dalam masyarakat tersebut tidak melakukan tingkeban dikhawatirkan akan dapat menerima sanksi sosial sehingga masyarakat tetap melanjutkan ritus ini sebagai sebuah kebudayaan turun temurun dengan kearifan lokal yang ada di dalamnya.

\section{Fungsi Tingkeban Di Masyarakat}

Ritus budaya tingkeban ini salah satu upacara yang dipercayai masyarakat untuk dapat mendoakan calon bayi dan meminta keselamatan agar bayi ini serta ibunya bisa selamat sampai proses kelahiran dan tingkeban memiliki suatu fungsi sosial yaitu sebagai perekat sosial antar masyarakat. Dalam pelaksanaan tingkeban atau mitoni ini memiliki suatu rangkaian kegiatan yang harus dilakukan. Seperti halnya proses siraman yang dilakukan oleh pihak keluarga dulu dimulai dari yang sesepuh yang bergantian sampai tetanggapun boleh untuk mengikuti proses siraman ini dimana keluarga dan masyarakat ikut serta menyiram air yang berisi bunga pada ibu yang hamil 7 bulan serta suaminya. Sehingga tidak hanya dari pihak keluarga saja yang ikut serta dalam proses siraman begitupula masyarakat sekitar ikut merasakan kebahagiaan sehingga timbul hubungan yang semakin dekat antara keluarga dan masyarakat tersebut. Kemudian, terdapat upacara ganti pakaian dimana sang ibu diminta untuk berganti pakaian atau istilah sewek yang diiringi dengan pertanyaan "sudah pantas belum?" hal tersebut menggambarkan terdapat sebuah hubungan keharmonisasian antar masyarakat. Ada pembagian tugas dimana ada yang membantu proses ganti pakaiannya dan ada yang menjawab dari pertanyaan bahwa pakaian tersebut pantas atau tidaknya. Adanya komunikasi tersebut dapat membuat kedekatan antar masyarakat.

Selain itu, terdapat kegiatan berupa tasyakuran yang dilakukan di malam hari. Bentuk tasyakuran ini seperti memanjatkan doa dan diujung acara diberi nasi dimana isinya seperti urap-urap, orem-orem tempe, ayam serta kue-kue yang telah dibuat oleh keluarga dan masyarakat dan ada juga beberapa kue yang harus memesan pada orang lain. Hal tersebut diadakan dengan mengundang ustadz, keluarga dan masyarakat (tetangga sekitar rumah). Tasyakuran ini diadakan untuk memohon dan meminta pada Allah SWT atas keselamatan sang bayi dan ibu agar bayi tersebut diberi kesehatan dan sang ibu juga dimudahkan dalam proses lahiran. Disini antara keluarga maupun masyarakat berkumpul di rumah yang memiliki hajat kemudian membacakan surat yasin, shalawat serta doa-doa. Mereka semua berkumpul bersama untuk memanjatkan doa. Kegiatan tasyakuran ini dilakukan dengan khitmat karena hal tersebut dapat dikatakan suatu kegiatan yang sakral untuk dilakukan. Tasyakuran ini diadakan dengan memanjatkan segala doa dan permohonan untuk calon bayi yang menjadi suatu harapan keluarga serta sang ibu diberi kemudahan dan kelancaran dalam proses persalinan. Ritus ini menjadi suatu kepercayaan bagi masyarakat terutama kalangan suku jawa dan menjadi sebuah simbol kebanggaan dan juga hal yang sangat ditunggu-tunggu bagi keluarga baru terutama pengantin baru untuk melengkapi keluarga dengan hadirnya anggota baru di keluarga tersebut agar melengkapi kebagiaan serta keharmonisan keluarga. Dengan ritus budaya tingkeban ini dapat menimbulkan keharmonisan pada sebuah hubungan secara internal maupun eksternal karena kegiatan ritual ini 
saling membantu dalam menyelesaikan tugas maupun kegiatannya sehingga antara satu dengan yang lain saling interaksi dan komunikasi dengan baik. Dalam artian, ritus ini sebagai perekat sosial antar masyarakat. Tidak hanya itu, bahkan ritus budaya tingkeban ini juga dapat menjadi alat pendidikan, upacara tersebut atau ritus budaya tingkeban ini menjadi sarana untuk berdoa kepada Allah SWT, sebagai sarana pemberitahuan bagi keluarga dan masyarakat atas kebahagiaan dari keluarga atas kehamilan dari sang ibu dan sudah berada di usia 7 bulan dan akan mencapai proses kelahiran karena menurut kepercayaannya bahwa hal tersebut suatu kebanggaan dari keluarga atas anugrah yang diberi Allah SWT dengan diberikan kepercayaan atas titipan yang Allah beri pada keluarga.

Ritus budaya tingkeban ini sebagai perekat sosial dan dalam melaksanakan ritus budaya tingkeban ini membutuhkan bantuan dari orang lain karena tidak bisa dilakukan secara individu. Ritus ini dilakukan secara bersama-sama dan gotongroyong. Seperti halnya mendirikan tenda itu membutuhkan tenaga banyak orang, seperti halnya juga membuat kue ataupun masakan yang akan disajikan pada tamu maupun keluarga tersebut. Hal ini pastinya membutuhkan tenaga banyak orang sehingga para keluarga maupun masyarakat berkumpul secara bersama-sama saling membantu dan pastinya mereka bertemu dengan interaksi maupun komunikasi yang baik dan pastinya mereka semua bergantung dalam saling membutuhkan. Dengan demikian, ritus budaya tingkeban sebagai perekat sosial antar masyarakat.

\section{Kesimpulan}

Dari pembahasan diatas, dapat kami simpulkan bahwasanya Ritus Budaya Tingkeban di jember ini, sudah dapat dikatakan hampir pudar karena masyarakat yang semakin modern mulai menganggap remeh kepercayaan ini sehingga ritus ini mulai jarang ditemui adanya tingkeban ini. Tingkeban ada karena masyarakat dulu memiliki kepercayaan didalamnya. Berbeda dengan zaman lampau bahwasanya seluruh masyarakat nenek moyang kita selalu melakukan ritus budaya tersebut karena kepercayaan yang ada pada pemikirannya bahwa kita harus memiliki rasa hormat terhadap roh yang akan lahir dalam perut ibu hamil. secara filosofis tingkeban ini mengandung sarat akan makna di dalamnya dan fungsi-fungsi sosial, akan tetapi ritus ini berfungsi untuk menjadi perekat sosial masyarakat yang sangat penting di era modern yang semakin individualis.

\section{References}

Ardra. (2020, May 31). Ardra.biz. Retrieved from Ardra.biz.com: https://ardra.biz/ciri-cirimasyarakat-modern-di-indonesia/.

Chandrarini. (2020, May 31). Chandrarini.com. Retrieved from Chandrarini: http://chandrarini.com/upacara-tingkebannujuh-bulanan/

Desitania, A. (2016). ANALISIS KELAYAKAN PENGEMBANGAN BISNIS SEBLAK PARYZA DI KOTA BANDUNG. repository.upi.edu, 40.

Forth, G. (2020, Juni 1). Researchgate. Retrieved from Researchgate: https://www.researchgate.net/publication/32 7462542_Rites_of_Passage

Hasbullah. (2012). REWANG: Kearifan Lokal dalam Membangun Solidaritas dan Integrasi Sosial Masyarakat Bukit Batu Kabupaten Bengkalis. Jurnal Sosial Budaya, 234.

Mulyadi. (2011). Penelitian Kuantitatif Dan Kualitatif Serta Pemikiran Dasar Menggabungkannya. Jurnal Studi Komunikasi Dan Media, 134.

Wikipedia. (2020, May 31). Wikipedia. Retrieved from Wikipedia.org: https://id.wikipedia.org/wiki/Zaman_moder $\mathrm{n}$ 